\title{
Üniversite Çalışanlarının Finansal Okuryazarlık Düzeylerinin Belirlenmesine Yönelik Bir Araştırma
}

\author{
Hakan Öndes ${ }^{\mathrm{a}, \mathrm{b}}$, Nuran Bayram Arlı ${ }^{\mathrm{c}}$
}

Özet

Bu çalışmada, üniversite personeline yönelik olarak finansal okuryazarlık seviyesinin incelenmesi amaçlanmıştır. Bu doğrultuda, hazırlanan anket bir kamu üniversitesinde 263 kişiye uygulanmıştır. Elde edilen veriler ışığında, açıklayıcı ve doğrulayıcı faktör analizi uygulanarak ölçeklerin güvenirlik ve geçerlilikleri tespit edilerek finansal okuryazarlık düzeyi belirlenmiştir. Açıklayıcı ve doğrulayıcı faktör analizleri sonucunda dört farklı ölçeğe ilişkin tek faktörlük yapılar elde edilmiş olup, faktörler toplam varyansın \%38 ile $\% 65$ 'lik kısmını açıklayabilmiştir. Her bir ölçeğe ilişkin elde edilen güvenirlik katsayıları, ölçeğin geçerli ve tutarlı veri toplama işlevine sahip olduğunu göstermiştir. Uyum iyiliği kriterleri de sonuçları açısından iyi bir uyuma işaret etmiştir. Gerçekleştirilen t testi ve varyans analizi; cinsiyet, medeni durum, finans takibi ve finansal varlıkların, finansal okuryazarlık düzeyi için istatistiksel olarak anlamlı farklılı̆̆a sahip olduğunu göstermiştir.
Anahtar Kelimeler

Finansal Okuryazarlık

Açıklayıcı ve Doğrulayıcı

Faktör Analizi

T Testi ve Varyans Analizi

Üniversite Personeli

Makale Hakkında

Geliş Tarihi: 01.10.2019

Kabul Tarihi: 05.10.2020

Doi: $10.18026 /$ cbayarsos.628037

\section{An Investigation On Determining The Financial Literacy Levels Of University Employees}

\begin{abstract}
In this study, it is aimed to examine the level of financial literacy for university staff. Accordingly, the preparing survey was applied to 263 people in a public university. In the light of the data obtained, explanatory and confirmatory factor analysis was used to determine the reliability and validity of the scales and also the level of financial literacy. As a result of factor analysis, four different scales were obtained related to single factor structures. Related factors could explain $38 \%$ to $65 \%$ of the total variance. The reliability coefficients obtained for each scale, the scale showed that has been a valid and consistent data collection function. Goodness of fit criteria also indicated good fit in terms of results. The $t$ test and variance anaysis showed that gender, marital status, financial follow-up and financial assets had statistically significant differences for the level of financial literacy.
\end{abstract}

Keywords

Financial Literacy

Explanatory and Confirmatory

Factor Analysis

T Test and Variance Analysis

University Staff

About Article

Received: 01.10.2019

Accepted: 05.10.2020

Doi: 10.18026/cbayarsos.628037

\footnotetext{
a İletişim Yazarı: hondes@bandirma.edu.tr

b Arş.Gör., Bandırma Onyedi Eylül Üniversitesi İ.İ.B.F. Ekonometri Bölümü/ BALIKESİR, ORCID: 0000-0002-0618-7705

c Prof.Dr., Bursa Uludağ Üniversitesi İ.İ.B.F. Ekonometri Bölümü/ BURSA, ORCID: 0000-0001-5492-184X.
} 


\section{Giriş}

Finansal okuryazarlık, karmaşık bir finansal yapıda faaliyet göstermesi gereken vatandaşlar için temel bir yetenek olarak bilinmektedir. Globalleşen dünyada teknolojinin ve telekomünikasyon ağının hızla ilerlemesi beraberinde finansal küreselleşmeyi getirmiştir. Türkiye'de ve farklı ülkelerde yönetimler, farklı eğitim seviyelerindeki kişilere öğrenme fırsatları sunmak amacıyla, nüfusun finansal okuryazarlık seviyesinin veya ulusal okuryazarlık stratejilerinin geliştirilmesi yoluyla finansal okuryazarlığın iyileştirilmesi için etkili yaklaşımlar bulmakla ilgilenmektedir (Atkinson ve Messy, 2012;25). Artan finansal araçlarla birlikte karmaşık yapıya bürünen finansal sistem etkin bir şekilde finansal okuryazar olma gereksinimini ortaya koymaktadır. Günlük hayattaki alışverişler ya da gereksinimler için alternatif kredi kartlarının karşılaştırılması, farklı ödeme seçenekleri arasında karar verme, yapılacak tasarrufların miktarı ve ileriye yönelik emeklilik planlarının nasıl değerlendirileceğ $i$ gibi sosyal yaşamda devamlı karşılaşılan sorunlar finansal okuryazarlığın önem derecesini yükseltmektedir. Bunun yanında, kişilerin kendi ve ailelerinin geleceklerini oluşturmada, tatil kredisi, ev peşinatı ve faiz, araç kredisi, bireysel emeklilik primleri ve diğer lüks mallar için finansal kararlarını optimum bir şekilde yönetmeleri gerekmektedir.

Finansal araçların çeşitliliğinin arttı̆̆ günümüzde, finansal okuryazarlık tüm tüketiciler için önemli bir yetenek olarak değerlendirilmektedir (Taylor ve Wagland, 2013;74). Bu sebeple gerekli olan ihtiyaç, bireylerin finansal okuryazarlık düzeylerini finansal araç çeşitliliğinin oluşturduğu karmaşık noktaya çıkarabilmeleridir. Bu durum, bireylerin finansal karar almada izleyeceği uygun yolu ve kazançlarının daha yüksek bir seviyeye gelmesini sağlayacaktır (Temizel ve Bayram, 2011;76).

Finansal okuryazarlık, finansal kararlılık ile finansal işlerin idaresi ve bireylerin refahı için önemli bir alandır (Lusardi ve Tufano, 2008;9). Finansal okuryazarlık, bireylerin finansal güvenliğini de sağlamasından dolayı her dönem üzerinde durulması ve sürekli güncel tutulması gereken bir konudur. Finansal okuryazarlık seviyesinin arttırılabilmesi için, öncelikle güncel finansal okuryazarlık seviyesinin tespiti gereklidir.

$\mathrm{Bu}$ amaç doğrultusunda, çalışmada üniversite personelinin finansal okuryazarlık düzeyinin belirlenmesi araştırılmaktadır. Bu araştırma kapsamında üniversite personelinin finansal okuryazarlık konusundaki bilgileri, hangi kaynaklardan hareketle finansal kararları oluşturduğu, finansal okuryazarlık hakkındaki yeterlilikleri, son dönem finansal gelişmeleri takip edip etmedikleri ve birtakım finansal terimleri bilip bilmedikleri ölçülmüştür. Çalışmada giriş kısmından sonra sırasıyla kavramsal yapıya, uygulanan yönteme ve bulgulara yer verilmiştir. Çalışma sonuç bölümü ile sonlandırılmıştır.

\section{Kavramsal Yapi}

Finansal okuryazarlık terimi sıklıkla finansal eğitim veya finansal bilgi ile eşanlamlı olarak kullanılsa da gerçekte, bu yapılar kavramsal olarak farklıdır ve bunları eş anlamlı olarak kullanmak, finansal okuryazarlı̆̆ın finansal bilgiden daha derin olması sebebiyle sorunlara yol açabilir. Huston (2010;299) finansal okuryazarlığın iki boyutu olduğunu söyler. Birincisi finansal eğitimin kişisel finansal bilgisini temsil eden anlayışı, ikincisi ise kişisel finansal bilgi yönetiminin uygulanması anlamına gelen anlayıştır. Hung ve diğerleri $(2009 ; 16)$ finansal eğitimi, insanların finansal ürünler ve hizmetler konusundaki kavramları geliştirdikleri bir süreç olarak tanımlamakta ve finansal okuryazarlık, kaynakları etkin bir şekilde yönetmek için edinilen bilgi ve becerileri kullanma, finansal refah sağlama yeteneği olarak 
tanımlanmaktadır. Mandel $(2007 ; 11)$ için finansal okuryazarlık, yeni ve karmaşık finansal araçları değerlendirme ve araç seçimi ile daha uygun kullanımına ilişkin olarak paranın kullanımına ilişkin etkili karar vermede rehberlik edilmesine ilişkin bilinçli yargılarda bulunma yeteneğini ifade eder.

Finansal okuryazarlık alanındaki ikilemlerden biri, finansal bilgi ve finansal eğitim arasındaki farkların anlaşılmasıdır. Bu anlamda, Robb ve diğerleri (2012;294) finansal okuryazarlı̆̆ın finansal bilgileri anlama ve bu bilgileri kullanarak etkili kararlar verebilme yeteneğini içerdiğini gösterirken, finansal eğitim sadece bir grup gerçeği veya sadece finansal bilgiyi hatırlama becerisidir. Criddle'a (2006;7) göre, finansal okuryazarlığa sahip olmak, finansal hedefler oluşturmak için birçok alternatif arasından seçim yaparken öğrenmeyi içerir. Sonuç olarak, finansal okuryazarlık, temel finansal eğitim fikrinden daha ileri gider.

Finansal okuryazarlık çalışmasındaki bir başka ikilem de finansal okuryazarlığı oluşturan kavramsal modellerin eksikliğidir. İncelenen literatüre göre, Huston (2010;301) değerlendirdiği yetmiş eserden elliden fazlasının finansal okuryazarlığı tanımlayamadığını ve tanımlanmış yirmi eserde finansal kabiliyete odaklanan iki tanım ve sadece finansal bilgiye odaklanan üç tanım tespit edilmiştir.

Finansal okuryazarlığı tanımlamak için kullanılan birçok tanım olmasına rağmen, pek çoğu; bir bireyin finansal refahını amaçlayan etkin bir karar verebilmek için gerekli olan finansal bilgileri edinme, anlama ve değerlendirme yeteneğini ifade etmektedir. Bu durum OECD'yi, finansal okuryazarlığı daha geniş bir çerçevede ele alan bir tanım bulmaya yöneltmiştir (Atkinson ve Messy, 2012;31). OECD, finansal okuryazarlığı beş boyutta tanımlar: Finansal bilgi, finansal davranış, finansal tutum, finansal tatmin ve kişisel servet.

Finansal bilgi, gelir, gider ve tasarrufları etkin bir şekilde yönetme kabiliyetini etkileyen öğrenme unsurları ile yaşam döngüsünde edinilen belirli bir insan sermayesi türü olarak önerilmiştir. Gruplar halinde bilgi iletirken ve alırken etkileşimler yoluyla geliştirilmiştir (Danes ve Haberman, 2007;53). Finansal tutum, Shockey (2002;24) tarafından öğrenme süreci ile ilgili kavramların, bilgilerin ve duyguların bir birleşimi olarak tanımlanır ve olumlu davranmak için bir eğilim oluşturur. Bu nedenle, finansal tutumların geliştirilmesi, bireylerin doğrudan deneyimlerinin bir sonucu olabilir (Winkielman ve diğ. 2006;800). Finansal davranış, finansal okuryazarlığın temel bir unsuru (International Wellbeing Group, 2013;8) olarak tanımlanırken, son zamanlarda yapılan çalışmalar finansal okuryazarlığın finansal okuryazarlık unsuru olarak ilişkilendirilmiştir (Lusardi ve Mitchell, 2013;14). Finansal tatmin, finansal yeterliliğe bağlı öznel bir refah ölçüsü olarak tanımlanmaktadır (Xiao ve diğ, 2011;242). Kişisel servet, finansal okuryazarlığın aktif ve istenilen ya da arzu edilenbir durumu ve "finansal memnuniyetin nesnel durumunu, finansal tutumları ve bir ölçümle değerlendirilemeyen davranışları içeren kapsamlı, çok boyutlu bir kavram" olarak tanımlanmaktadır (Joo, 2008;25).

Araştırmaciların finansal okuryazarlığı ölçtüğü bir "ortak" veya "olağan" yöntemin olmadığ1 yapılan çalışmalar da görülmüştür. Ancak bu durum, finansal okuryazarlığın literatürde tutarlı bir şekilde ve pratik olarak ölçülmediği anlamına gelmemektedir. Annamaria Lusardi ve Olivia Mitchell, birçok çalışmada yaygın olarak kullanılan üç sorudan oluşan bir grup geliştirdiler (Knoll ve Houts, 2012;384). Sorular, finansın üç temel kavramını kavramaktadır. Bunlar vergi oranı, enflasyon ve riskten kaçınmadır. Bu soruların faydası, finansal 
okuryazarlık açısından ülkeler arasında karşılaştırma yapmak için yararlı bir temel oluşturan, pek çok araştırmanın konusu oldukları gerçeğinde yatmaktadır.

\section{Literatür Taraması}

Chen ve Volpe (1998), 924 üniversite öğrencisine kişisel finansal okuryazarlıklarını incelemek için araştırma yapmıştır. Finansal okuryazarlık ve öğrencilerin özellikleri arasındaki ilişki ve okuryazarlığın öğrencilerin görüş ve kararları üzerindeki etkisi incelenmiştir. Sonuçlar katılımcıların soruların yaklaşık\% 53'ünü doğru cevap verdiğini göstermiştir. İşsizler, kadınlar, alt sınıftaki öğrenciler, 30 yaş altı ve çok az iş tecrübesi olan öğrenciler daha düşük bilgi seviyesine sahip olduğu sonucu elde edilmiştir. Cinsiyet açısından değerlendirildiğinde mevcut çalışmada bulunan benzerlik gereği erkekler finansal okuryazarlık düzeyinde daha başarılıdır.

Jorgensen ve Savla (2010) finansal okuryazarlık seviyelerinde aile etkisini test etmek için, 420 üniversite eğitimi alan gençlere yönelik anket hazırlanmıştır. Analiz kısmında gerçekleştirilen yapısal eşitlik modellemesi ile elde edilen bulgulara göre aile etkisinin finansal tutum ve davranışlar üzerinde anlamlı buna karşılık finansal bilgi düzeyinde ise anlamsız olduğu tespit edilmiştir.

Sohn ve diğerleri (2012), Koreli genç nüfus adına finansal sosyalleşme etkenleri, finansal deneyimler, para tutumları, demografik özellikler ve finansal okuryazarlığı arasındaki ilişkileri test etmiştir. 2006 Kore Ulusal Mali Okuryazarlık Test Araştırması kullanılarak, finansal okuryazarlıkla ilgili faktörleri belirlemek için bir dizi regresyon analizi yapılmıştır. Medyayı birincil finansal sosyalleşme etkeni olarak seçenlerin ve bir banka hesabına sahip olanların daha yüksek düzeyde finansal okuryazarlık gösterdikleri tespit edilmiştir. Kore'de genç nüfus üzerinde etkili olan bu durumun benzer sonuçları mevcut çalışmada üniversite personelinde görülmüştür. Finansal varlık takibi ve internet/mobil kullanımı finansal okuryazarlık düzeyini anlamlı şekilde etkilemiştir.

Ansong ve Gyensare (2012), Gana'daki bir devlet üniversitesinin 250 lisans ve lisansüstü öğrencisinden rastgele toplananla veriler ile finansal okuryazarlık ve belirli demografik özellikler arasındaki ilişkiyi incelemişlerdir. Bulgular, yaş ve iş tecrübesinin finansal okuryazarlığı pozitif etkilediğini göstermiştir. Bu çalışma bu anlamda mevcut çalışmadan farklılık göstermiştir. Önemli bir bulgu ise, ebeveynlerin eğitimleri ile finansal okuryazarlık düzeyi arasında pozitif korelasyon elde edilmiştir. Bu sonuç finans konularının ortaöğretim eğitim programlarında yer alması gerektiğini işaret etmektedir. Bu kanıya çalışmanın sonuç kısmında da değinilmiştir.

Taft ve diğerleri (2013) çalışmalarında finansal okuryazarlık, finansal refah ve finansal endişeler arasındaki ilişkiyi değerlendirmiştir. Çalışmada kullanılan değişkenler mevcut çalışma ile karşılaştırıldığında bir kısmını içermektedir. Rassal örnekleme kullanılarak bir anket hazırlanmış ve dağıtılmıştır. Veriler korelasyon testi, $\mathrm{t}$ dağılımı ve regresyona dayanan bağımsız iki örneklem testi kullanılarak analiz edilmiştir. Sonuçlar, yaş ile eğitim durumunun, finansal okuryazarlık ve finansal refah ile pozitif ilişkili olduğunu göstermiştir. Evli ve erkekler daha finansal okuryazardır. Bu sonuç mevcut çalışmamızla birebir örtüşmektedir. Daha yüksek finansal okuryazarlık, daha fazla finansal refah ve daha az finansal kaygılarla sonuçlanmıştır.

Potrich ve diğerleri (2015),finansal okuryazarlığ finansal davranıştan meydana gelen bir ölçek geliştirmiştir. Bu anlamda, Güney Brezilya'da 
yaşayan 991 kişiyle anket yapılmıştır. Çalışma oluşturulan ölçek anlamında mevcut çalışmaya benzerlik gösterse de mevcut çalışmada ek olarak kişisel servet ve finansal stres/refah ölçekleri yer almaktadır. Toplanan verilerin analizinde, YEM kullanılmıştır. Yapılan testler bu modelin hem kadın hem de erkek için yeterli olduğunu göstermiştir. Ancak erkek bireyler, kadınlara göre ortalama olarak daha yüksek düzeyde bir finansal okuryazarlık göstermiştir. Bu sonuç mevcut çalışma ile benzerlik göstermiştir.

Alkaya ve Yağlı (2015), bir kamu üniversitesinde eğitim gören öğrencilerinin finansal bilgi, tutum ve davranışlarını araştırmayı amaçlamışlardır. Finansal okuryazarlık düzeyleri, frekans yüzde dağılımlarıyla belirlenmeye çalışılmıştır. Ki-kare bağımsızlık sınamasıyla demografik özellikler ile finansal bilgi, tutum ve davranış arasında ve finansal okuryazarlık unsurları arasındaki ilişkiler araştırılmıştır. Elde edilen bulgulara göre finansal tutum ile finansal davranış arasında ilişki olduğu ve öğrencilerin olumlu finansal davranış ve tutumlar sergiledikleri ancak öğrencilerin finansal bilgi açısından yeterli düzeyde olmadıkları belirlenmiştir.

Öztürk ve Demir (2015), kamu üniversite personeline yönelik olarak finansal okuryazarlık ve para yönetimine ilişkin finansal bilgileri, finansal davranışları ve tutumları ölçerek finansal okuryazarlık düzeyini belirlemeyi amaçlamıştır. Elde edilen bulgulara göre akademik personelin finansal okuryazar seviyesinin yeterli olduğu ancak finansal eğitime gereksinim duydukları saptanmıştır.

Çoşkun (2016) makalesinde, bir kamu üniversitesinde ön lisans öğrencilerine yönelik finansal okuryazarlık düzeyini araştırmak istemiştir. Finansal okuryazarlık bilincinin finansal davranışları ve tutumlarını ne şekilde ve ne yönde etkilediğini tespit edebilmek amacıyla belirlenen ölçek üzerinden anket çalışması yapılmıştır. Elde edilen bulgular frekans dağılımı yöntemi ile açıklanmıştır. Buna göre öğrencilerin sahip olduğu finansal ürünler hakkında bilgili olduğu, finansal ürünlerin seçimi ve kullanımı konusunda bilinçli olduğu bununla birilikte elde ettikleri gelirleri nasıl yöneteceklerini çok da iyi bilmedikleri sonuçlarına varılmıştır.

Şahin ve Barış (2017) çalışmalarında, kamu çalışanlarının finansal okuryazarlık düzeylerini ve bu düzeylerin tasarruf davranışları üzerine etkisini incelemişlerdir. Tokat'ta 427 kamu çalışanına uygulanan anket verileri lojistik regresyon analizine tabi tutulmuştur. Analizden sağlanan bulgular yaş, hanehalkı geliri, finansal gelişmeleri takip etme durumu ve temel/ileri düzey finansal okuryazar olmanın tasarruf davranışı üzerinde anlamlı ve pozitif etkiye sahip olduğunu göstermiştir.

Ergün (2018) çalışmasında, Estonya, Almanya, İtalya, Hollanda, Polonya, Romanya, Rusya Federasyonu ve Türkiye'deki üniversite öğrencileri arasında finansal okuryazarlık seviyesini analiz etmiştir. Çalışmanın amacı, üniversite öğrencileri arasında finansal okuryazarlık seviyesini belirlemek ve öğrencilerin finansal bilgiler ile demografik özellikleri arasındaki ilişkiyi incelemektir. Analiz için 409 adet tamamlanmış anket kabul edilmiştir. Demografik özelliklerin finansal okuryazarlık üzerindeki etkilerini analiz etmek için lojistik regresyon kullanılmıştır. Sonuçlar, erkek öğrencilerin, işletme lisans öğrencilerinin, doktora öğrencilerinin, bir kiralık evde yaşayanların, ebeveynleri yüksek gelir seviyesine sahip olanların, arkadaşlarından finansal konularda tavsiyede bulunanların, daha önce finansal kurs alanların, daha önce finansal ders alanların finansal okuryazarlık düzeylerinin daha yüksek olduğunu göstermiştir. 
Bağ cı ve Arabacı (2019), bir kamu üniversitesinde öğrenim gören öğrencilerin finansal okuryazarlık düzeylerini ve finansal okuryazarlıklarının hangi faktörlerden etkilendikleri incelenmişlerdir. Elde edilen bulgular öğrencilerin finansal okuryazarlık düzeylerinin düşük seviyede olduğunu göstermiştir. Ayrıca finansal okuryazarlık düzeyinin; ailenin geliri, babanın mesleği, kredi kartına sahip olma, kredi kartı limiti, kredi kartının asgari tutarını ödeyebilme, gelir-gider düzeyi, temel finans bilgisi, finansal okuryazarlık eğitimi, hangi finansal araçlara hangi bilgi kaynakları kullanılarak yatırım yapıldığı 1 ve finansal okuryazarlık yeterliliği faktörlerinden etkilendiği tespit edilmiştir.

Literatürde yer alan çalışmaların genel yapısı finansal okuryazarlık düzeyini etkileyen unsurları belirlemek ve aralarında ilişkileri tespit etmektir. Bu çalışma da benzer bir amaçla oluşturulmuştur. Diğer çalışmalardan farkı, finansal okuryazarlık düzeyini etkileyen unsurları belirlerken finansal okuryazarlığı beş farklı ölçeğin bileşiminden elde etmesidir. Çalışmalarda bu ölçeklerden bir veya birkaçı kullanılsa da bu çalışmada tamamına yer verilmiştir. Çalışmada üniversite öğrencilerinden ziyade eğitim-öğretim hayatını tamamlamış ve meslek sahibi olmanın getirdiği sorumluluktan hareketle finansal varlıklara daha ilgili olabileceğini düşünülen üniversite çalışanlarına yer verilmiştir.

\section{Yöntem}

Çalışmanın örneklemi bir kamu üniversitesinde çalışan akademik ve idari personelden oluşmaktadır. Örneklemde yer alan birimler basit rassal örnekleme yöntemi ile seçilmiştir. Araştırma yapılan dönem itibariyle üniversitenin akademik ve idari birimleri içlerinde anakütleyi oluşturan toplam 587 personel bulunmaktadır. Saunders vd. (2000)'nin \%97 güven düzeyinde farklı ana kütle büyüklükleri için örnek hacimlerinin verildiği çalışmasında 587 kişi olan anakütleden 340 kişilik bir örneklemeye ulaşılabileceği görülmektedir. Bir sonraki aşamada personele anket uygulanmıştır. Dağıtılan toplam 340 anketten geri dönmeyenler ve işlemez durumda olan anketler ayıklandığında geriye 263 anket kalmıştır. Dolayısıyla çalışmaya 263 kişi katılmıştır.

Katılımcıların yaklaşık \%44'ü kadın ve \%56'sı akademisyendir. Bu çalışmada bireylerin finansal okuryazarlık düzeylerini belirlemek için Kişisel Refah, Finansal Stres/Refah, Finansal Okuryazarlık Tutum, Finansal Okuryazarlık Davranış ve Finansal Okuryazarlık Bilgi olmak üzere 5 ölçekten yararlanılmıştır. Bu çalışmada ilk dört ölçek için açıklayıcı ve doğrulayıcı faktör analizleri yapılmıştır.

Kişisel Refah Ölçeği (The Personal Wellbeing Index - Adult (PWI-A)): 18 yaş üstü bireylerin kişisel refahını ölçmek için kullanılan ölçek yedi maddeden oluşmaktadır. Ölçekte yer alan maddeler Uluslararası Refah Grubu tarafından hazırlanan yetişkinlere ilişkin Kişisel Refah Endeksi kullanılarak ölçülmüştür (PWI-A, 5th Edition, The International Wellbeing Group, 2013). PWI - A ölçeği, yaşam standardı, sağlık, yaşamda başarı, ilişkiler, güvenlik ve topluluğa bağlılık gibi bireylerin yaşam kalitesini etkiyen memnuniyet maddelerini içermektedir. $\mathrm{Bu}$ maddeleri içeren alanlar ile birlikte "Kişisel durumunuzu düşündüğünüzde hayatınızdan ne kadar memnunsunuz?" maddesi de ölçekte yer almaktadır. Ölçek 1-Kesinlikle memnun değilim ve 5-Kesinlikle memnunum şeklinde 5'li likert ile ölçülmüştür. Yükssek puanlar kişisel refahın yüksek olduğunu göstermektedir.

Finansal Stres/Refah Ölçeği (In Charge Financial Distress/Financial Well-Being Scale - IFDFW): Ölçekte yer alan sorular Prawitz ve diğ. (2006) yaptıkları çalışmadan oluşturulmuştur. Altı maddeden oluşan IFDFW ölçeğinin Beta versiyonu ile bireylerin finansal durumlarına yönelik 
algılanan stres ve refah düzeyi ölçülmeye çalışılmaktadır. Bu çalışmada ölçeğin beş maddesi kullanılmıştır. Bu amaçla beş maddeden oluşan ölçekte üç soru (ters olarak kodlanır) bireylerin finansal stres düzeyini iki soru da bireylerin finansal refah düzeyini ölçmektedir. Ölçek 1-Oldukça az ve 5-Oldukça fazla şeklinde 5'li likert ile ölçülmüştür. Yüksek puanlar algılanan finansal refahın yüksek olduğunu göstermektedir.

Finansal Okuryazarlık - Tutum Ölçeği (Financial Literacy Attitude (FL-A) Scale): Bireylerin finansal tutumunu ölçmek için sekiz maddeden oluşan ve Shockey (2002) tarafından geliştirilen ölçek kullanılmıştır. Ölçeğin Türkçe uyarlamasında 7 madde kullanılmıştır. Ölçekte "aylık giderleri kontrol etmek önemlidir" gibi ifadelere yer verilmiştir. Maddelerden bir tanesi ters kodlanmıştır. Ölçek 1-Kesinlikle katılmıyorum ve 5-Kesinlikle katılıyorum şeklinde 5'li likert ile ölçülmüştür. Yüksek puanlar bireylerdeki finansal tutumun yüksek olduğunu göstermektedir.

Finansal Okuryazarlık - Davranış Ölçeği (Financial Literacy Behavior (FL-B) Scale): Bireylerin finansal davranışını ölçmek için Chen veVolpe (1998), Johnson (2001) ve Shockey (2002) tarafından geliştirilen ölçekler dikkate alınarak Türkiye gerçekliğine göre değiştirilmiş. Böylece yedi maddeden oluşan finansal davranış ölçeği ortaya konulmuştur. Ölçekte "faturalarımı geciktirmeden ödüyorum" gibi ifadelere yer verilmiştir. Maddelerden üç tanesi ters kodlanmıştır. Ölçek 1-Kesinlikle katılmıyorum ve 5-Kesinlikle katılıyorum şeklinde 5'li likert ile ölçülmüştür. Yüksek puanlar bireylerdeki finansal davranışının yüksek olduğunu göstermektedir.

Finansal Okuryazarlık - Bilgi Ölçeği (Financial Literacy Knowledge (FL-K) Scale): Bireylerin finansal bilgi düzeylerini ölçmek için Louw ve diğ. (2013), Chen ve Volpe (1998), Knoll ve Huts (2012), Chinen ve Endo (2012) tarafından kullanılan sorular Türkiye şartlarına göre değiştirilerek (Örn. Enflasyon oranı, KDV oranı, emeklilik yaşı vb.) kullanılmıştır. Ölçek doğru ve yanlış cevap şeklinde 8 maddeden oluşmaktadır. Ölçekte yer alan maddelerden ikisi doğru (4. ve 7. maddeler), altı tanesi (1., 2., 3., 5., 6. ve 8. maddeler) yanlıştır. Buna göre bireylerin finansal bilgi düzeyi bu sekiz soruya verilen doğru cevapların toplam puanına eşittir. Ölçekten alınan puanlar en düşük 0 en yüksek 8 olarak değişmektedir. Yüksek puanlar bireylerin finansal bilgi düzeyinin yüksek olduğunu göstermektedir.

Çalışmada betimsel istatistiklerin yanı sıra ölçeklerin Türkçe geçerliliği için açıklayıcı ve doğrulayıcı faktör analizlerine yer verilmiştir. Ölçekte yer alan sorulara cevaplayıcıların verdikleri yanıtların tutarlılığını tespit etmek amacıyla Cronbach Alfa hesaplanmıştır. Cronbach Alfa değerinin 0.70'in üzerinde olması ölçeklerin tutarlı olduğunu göstermektedir (Bayram, 2016;77).

Yapılan tüm açıklayıcı faktör analizinin uygulanmasında, başlangıç faktör katsayılarının belirlenmesi için temel bileşenler analizi ve özdeğeri 1'den büyük faktör sayısı ile faktör yüklerinin 0,30'dan büyük olması kısıtları ele alınmıştır (Kalaycı, 2006;328).

Doğrulayıcı faktör analizi tahminlerinde maksimum olabilirlik tahmin yöntemi kullanılmıştır. Uyum iyiliğinin değerlendirilmesinde Ki-Kare İstatistiği $(\chi 2 / s d<5)$; Uyum İyiliği İndeksi (GFI>0,90); Karşılaştırmalı Uyum İndeksi (CFI>0,90); Yaklaşık Hataların Ortalama Kare Kökü (RMSEA<0,10); Standardize Edilmiş Kalıntıların Ortalama Kare Kökü $(S R M R<0,10)$ ölçüleri kullanılmıştır (Bayram, 2017;66; Schumacker ve Lomax, 2010;71; Yılmaz ve Varol, 2015;56). 


\section{Bulgular}

Tablo 1'de katılımcılara ilişkin betimsel istatistikleri yer almaktadır. 263 kişiden oluşan örneklem üzerinden yürütülen çalışmaya katılanların yaklaşı $\% 56$ 'sı erkek \%40'1 memur, \%32'si 34-41 yaş aralığındadır.

Tablo 1. Betimsel İstatistikler

\begin{tabular}{llll}
\hline \multicolumn{1}{c}{ Değişkenler } & & Frekans & Oran \\
\hline \multirow{2}{*}{ Cinsiyet } & Kadın & 115 & 43,7 \\
Kadro & Erkek & 148 & 56,3 \\
& Akademisyen & 157 & 59,7 \\
& Memur & 106 & 40,3 \\
Yaş & $18-25$ yaş & 19 & 7,2 \\
& $26-33$ yaş & 80 & 30,4 \\
& $34-41$ yaş & 83 & 31,6 \\
Medeni Durum & $42-49$ yaş & 55 & 20,9 \\
& $50+$ & 26 & 9,9 \\
Eğitim Durumu & Bekâr & 81 & 30,8 \\
& Evli & 182 & 69,2 \\
& Lise & 59 & 22,4 \\
Gelir Grupları & Lisans & 47 & 17,9 \\
& Lisansüstü & 157 & 59,7 \\
& $2501-3500$ TL & 106 & 40,3 \\
& 3501-4500 TL & 36 & 13,7 \\
Finans Takibi & $4501-5500$ TL & 59 & 22,4 \\
& 5501 TL + & 62 & 23,6 \\
& Takip etmem & 86 & 32,7 \\
Finansal Varlıklar & Tv & 44 & 16,7 \\
& Gazete & 50 & 19,0 \\
& İnternet/mobil & 83 & 31,6 \\
& Yok & 57 & 21,7 \\
& Var & 206 & 78,3 \\
\hline
\end{tabular}

Katılımcların yaklaşık \%31'i bekar, \%60'1 lisansüstü eğitime sahip, \%40'1 2501-3500 TL gelir düzeyine sahiptir. Bunların yanı sıra katılımcıların yaklaşık \%32'si finansal takiplerini internet/mobil üzerinden yaptığını ve \%78'inin de finansal varlıklara sahip olduklarını belirtmişlerdir.

Tablo 2' de kişisel servet ölçeğine ilişkin açıklayıcı ve doğrulayıcı faktör analizi sonuçlarına yer verilmiştir. Analiz sonucunda elde edilen KMO (Kaiser-Mayer-Olkin) değeri 0,846 olduğu için örneklem büyüklügüünun yeterli olduğu söylenebilir. Bartlett testi sonucunda (ChiSquare=1010,848; df:21; p<0.000) korelasyon matrisinin birim matris olmadı̆̆ 1 elde edilmiştir. Bu sonuçlara göre örneklemeye faktör analizi uygulanabilmektedir.

Tablo 2. KS Ölçeğinin Açıklayıcı ve Doğrulayıcı Faktör Analizi Sonuçları ve C. Alpha Değeri

\begin{tabular}{|c|c|c|c|c|c|c|}
\hline & & AFA & DFA & & & \\
\hline Kişisel Servet & $\begin{array}{c}\text { Ortak Faktör } \\
\text { Varyansları }\end{array}$ & $\begin{array}{l}\text { Faktör } \\
\text { Yükleri }\end{array}$ & $\begin{array}{l}\text { Faktör } \\
\text { Yükleri }\end{array}$ & Ortalama & S.Sapma & C. Alpha \\
\hline KS1 & 668 & 817 & ,786 & 28,71 & 5,158 & 89 \\
\hline KS2 & 683, & 826 & 866 & & & \\
\hline
\end{tabular}




\begin{tabular}{cccc} 
KS3 &, 511 &, 715 &, 647 \\
KS4 &, 685 &, 828 &, 770 \\
KS5 &, 543 &, 737 &, 744 \\
KS6 &, 630 &, 794 &, 690 \\
KS7 &, 548 &, 740 &, 643 \\
\hline Açıklanan & 60,962 \\
Varyans & \\
\hline
\end{tabular}

Açıklayıcı faktör analizi sonucunda tek faktörlük yapı elde edilmiştir. Bu faktör toplam varyansın yaklaşık olarak \%61'ini açılamıştır. Faktör yükleri yaklaşık 0,72-0,83 arasında değişmiştir.

Doğrulayıcı faktör analizi sonucunda tahmin edilen tüm katsayılar istatistiksel olarak anlamlı bulunmuştur. Standardize edilmiş faktör yükleri yaklaşık 0,64-0,87 arasında değişmiştir. Bu ölçek için Cronbach Alfa değeri 0,89 olarak hesaplanmıştır.

Tablo 3. KS Ölçeğinin Uyum İyiliği Değerleri

\begin{tabular}{cccccc}
\hline & $\chi^{2} / \mathbf{d f}$ & GFI & CFI & RMSEA & SRMR \\
\hline Hata Korelasyonsuz model & 10,33 & 0,87 & 0,87 & 0,18 & 0,06 \\
Hata Korelasyonlu model & 4,42 & 0,95 & 0,96 & 0,11 & 0,04 \\
\hline
\end{tabular}

Tablo 3'te hata korelasyonsuz ve korelasyonlu uyum iyiliği değerleri gösterilmiştir. Genel olarak bakıldığında hata korelasyonlu modelin uyum iyiliği değerleri daha iyi çıkmıştır. $\chi^{2} / \mathrm{df}$ değeri 4,42; GFI değeri 0,95; CFI değeri 0,96; RMSEA 0,11 ve SRMR=0,04 olarak bulunmuştur. Bu sonuçlar kabul edilebilir uyuma işaret etmektedir.

Finansal stres/refah ölçeğine ilişkin açıklayıcı ve doğrulayıcı faktör analizi sonuçlarına Tablo 4 'te yer verilmiştir. Analiz sonucunda elde edilen KMO değeri 0,831 olduğu için örneklem büyüklügünün yeterli olduğu söylenebilir. Bartlett testi sonucunda (Chi-Square=631,237; df:10; $p<0.000$ ) korelasyon matrisinin birim matris olmadığı elde edilmiştir. Bu sonuçlara göre veri grubuna Faktör Analizi uygulanabilir.

Tablo 4. FS/FR Ölçeğinin Açıklayıcı ve Doğrulayıcı Faktör Analizi Sonuçları ve C. Alpha Değeri

\begin{tabular}{|c|c|c|c|c|c|c|}
\hline & & AFA & DFA & & & \\
\hline & $\begin{array}{c}\text { Ortak Faktör } \\
\text { Varyansları }\end{array}$ & Faktör Yükleri & $\begin{array}{l}\text { Faktör } \\
\text { Yükleri }\end{array}$ & Ortalama & S.Sapma & C. Alpha \\
\hline FS1 & ,549 & 741 & 609 & 19,74 & 4,037 & 0,85 \\
\hline FR2 & ,732 & 855 & ,774 & & & \\
\hline FS3 & 791 & 889 & ,909 & & & \\
\hline FR5 & 615 & ,784 & ,717 & & & \\
\hline FS6 &, 574 & ,758 & 699 & & & \\
\hline $\begin{array}{c}\text { Açıklanan } \\
\text { Varyans }\end{array}$ & & 65,218 & & & & \\
\hline
\end{tabular}


Açıklayıcı faktör analizi sonucunda tek faktörlük yapı elde edilmiştir. Bu faktör toplam varyansın yaklaşık olarak \%65'ini açılamıştır. Faktör yükleri yaklaşık 0,74-0,89 arasında değişmiştir.

Doğrulayıcı faktör analizi sonucunda tahmin edilen tüm katsayılar istatistiksel olarak anlamlı bulunmuştur. Standardize edilmiş faktör yükleri yaklaşık 0,61-0,91 arasında değişmiştir. Bu ölçek için Cronbach Alfa değeri 0,85 olarak hesaplanmıştır.

Tablo 5. FS/FR Ölçeğinin Uyum İyiliği Değerleri

\begin{tabular}{lrrrrr}
\hline & \multicolumn{1}{c}{$\chi^{2 / d f}$} & \multicolumn{1}{c}{ GFI } & \multicolumn{1}{c}{ CFI } & RMSEA & SRMR \\
\hline Hata Korelasyonsuz model & 6,52 & 0,95 & 0,96 & 0,14 & 0,04 \\
Hata Korelasyonlu model & 2,82 & 0,98 & 0,99 & 0,08 & 0,02 \\
\hline
\end{tabular}

Genel olarak bakıldığında hata korelasyonlu modelin uyum iyiliği değerleri daha iyi çıkmıştır. $\chi^{2} / \mathrm{df}$ değeri 2,82; GFI değeri 0,98; CFI değeri 0,99; RMSEA 0,08 ve SRMR=0,02 olarak bulunmuştur. Bu sonuçlar iyi bir uyuma işaret etmektedir.

Finansal tutum ölçeğine ilişkin açıklayıcı ve doğrulayıcı faktör analizi sonuçlarına Tablo6'dayer verilmiştir. Analiz sonucunda elde edilen KMO değeri 0,686 olduğu için örneklem büyüklüğünün yeterli olduğu söylenebilir. Bartlett testi sonucunda (ChiSquare=404,419; df:21; $\mathrm{p}<0.000$ ) korelasyon matrisinin birim matris olmadığ 1 elde edilmiştir. Bu sonuçlara göre veri grubuna faktör analizi uygulanabilir.

Tablo 6. FT Ölçeğinin Açıklayıcı ve Doğrulayıcı Faktör Analizi Sonuçları ve C. Alpha Değeri

\begin{tabular}{ccccccc}
\hline & \multicolumn{7}{c}{ AFA } & DFA & & & \\
\hline & $\begin{array}{c}\text { Ortak Faktör } \\
\text { Varyanslar1 }\end{array}$ & $\begin{array}{c}\text { Faktör } \\
\text { Yükleri }\end{array}$ & $\begin{array}{c}\text { Faktör } \\
\text { Yükleri }\end{array}$ & Ortalama & S.Sapma & C.Alpha \\
\hline FTUT1 &, 737 &, 858 &, 993 & 30,08 & 2,615 &, 72 \\
FTUT2 &, 352 &, 593 &, 499 & & & \\
FTUT3 &, 472 &, 687 &, 600 & & & \\
FTUT4 &, 336 &, 579 &, 421 & & \\
FTUT5 &, 289 &, 537 &, 261 & & \\
FTUT6 &, 330 &, 574 &, 417 & & \\
FTUT7 &, 171 &, 414 &, 283 & & \\
\hline Aç1klanan & & 38,372 & & & \\
Varyans & &
\end{tabular}

Açıklayıcı faktör analizi sonucunda tek faktörlük yapı elde edilmiştir. Bu faktör toplam varyansın yaklaşık olarak \%38'ini açılamıştır. Faktör yükleri yaklaşık 0,41-0,86 arasında değişmiştir.

Doğrulayıc faktör analizi sonucunda tahmin edilen tüm katsayılar istatistiksel olarak anlamlı bulunmuştur. Standardize edilmiş faktör yükleri yaklaşık 0,26-0,99 arasında değişmiştir. Bu ölçek için Cronbach Alfa değeri 0,72 olarak hesaplanmıştır.

Tablo 7. FT Ölçeğinin Uyum İyiliği Değerleri

\begin{tabular}{lrrrrr}
\hline & \multicolumn{1}{c}{$\chi^{2 / d f}$} & GFI & \multicolumn{1}{c}{ CFI } & RMSEA & SRMR \\
\hline Hata Korelasyonsuz model & 5,54 & 0,93 & 0,84 & 0,13 & 0,08 \\
Hata Korelasyonlu model & 2,64 & 0,97 & 0,95 & 0,07 & 0,05 \\
\hline
\end{tabular}


Genel olarak bakıldığında hata korelasyonlu modelin uyum iyiliği değerleri daha iyi çıkmıştır. $\chi^{2} / \mathrm{df}$ değeri 2,64; GFI değeri 0,97; CFI değeri 0,95; RMSEA 0,07 ve SRMR=0,05 olarak bulunmuştur. Bu sonuçlar iyi bir uyuma işaret etmektedir.

Tablo 8'de finansal davranış ölçeğine ilişkin açıklayıcı ve doğrulayıcı faktör analizi sonuçlarına yer verilmiştir. Analiz sonucunda elde edilen KMO değeri 0,762 olduğu için örneklem büyüklüğünün yeterli olduğu söylenebilir. Bartlett testi sonucunda (ChiSquare=546,050; df:21; $\mathrm{p}<0.000$ ) korelasyon matrisinin birim matris olmadığ 1 elde edilmiştir. $\mathrm{Bu}$ sonuçlara göre veri grubuna faktör analizi uygulanabilir.

Tablo 8. FD Ölçeğinin Açıklayıcı ve Doğrulayıcı Faktör Analizi Sonuçları ve C. Alpha Değeri

\begin{tabular}{ccccccc}
\hline & \multicolumn{7}{c}{ AFA } & DFA & & & \\
\hline & $\begin{array}{c}\text { Ortak Faktör } \\
\text { Varyanslar1 }\end{array}$ & $\begin{array}{c}\text { Faktör } \\
\text { Yükleri }\end{array}$ & $\begin{array}{c}\text { Faktör } \\
\text { Yükleri }\end{array}$ & Ortalama & S.Sapma & C. Alpha \\
\hline FD1 &, 670 &, 818 &, 693 & 25,47 & 5,017 & 0,76 \\
FD2 &, 408 &, 639 &, 444 & & & \\
FD3 &, 677 &, 823 &, 905 & & & \\
FD4 &, 241 &, 491 &, 291 & & \\
FD5 &, 519 &, 720 &, 729 & & \\
FD6 &, 302 &, 549 &, 466 & & \\
FD7 &, 277 &, 527 &, 285 & & & \\
\hline $\begin{array}{c}\text { Aç1klanan } \\
\text { Varyans }\end{array}$ & & 44,201 & & & & \\
\hline
\end{tabular}

Açıklayıcı faktör analizi sonucunda tek faktörlük yapı elde edilmiştir. Bu faktör toplam varyansın yaklaşık olarak \%44'ünü açıklamıştır. Faktör yükleri yaklaşık 0,53-0,82 arasında değişmiştir.

Doğrulayıcı faktör analizi sonucunda tahmin edilen tüm katsayılar istatistiksel olarak anlamlı bulunmuştur. Standardize edilmiş faktör yükleri yaklaşık 0,29-0,91 arasında değişmiştir. Bu ölçek için Cronbach Alfa değeri 0,76 olarak hesaplanmıştır.

Tablo 9. FD Ölçeğinin Uyum İyiliği Değerleri

\begin{tabular}{cccccc}
\hline & $\chi^{2 / d f}$ & GFI & CFI & RMSEA & SRMR \\
\hline Hata Korelasyonsuz model & 7,14 & 0,90 & 0,84 & 0,15 & 0,08 \\
Hata Korelasyonlu model & 4,22 & 0,95 & 0,93 & 0,11 & 0,06 \\
\hline
\end{tabular}

Genel olarak bakıldığında hata korelasyonlu modelin uyum iyiliği değerleri daha iyi çıkmıştır. $\chi^{2} /$ df değeri 4,22; GFI değeri 0,95; CFI değeri 0,93; RMSEA 0,11 ve SRMR=0,06 olarak bulunmuştur. Bu sonuçlar kabul edilebilir bir uyuma işaret etmektedir.

Finansal bilgi kriterilikert tipi bir ölçek oluşturmadığı için ve katılımcıların finansal konulardaki bilgilerini ölçerken doğru, yanlış ve fikrim yok seçeneklerinden oluşturulduğundan açıklayıcı ve doğrulayıcı faktör analizi sonuçlarını içermemektedir. 
Çalışmada ölçek geçerlilikleri ve tutarlı uyum iyiliği değerleri sonucunda 5 farklı değişkenin birleşimi finansal okuryazarlığı oluşturmaktadır. Bir başka ifade ile kişisel servet, finansal stres/refah, finansal tutum, finansal davranış ve finansal bilgi ölçekleri finansal okuryazarlığ meydana getirmektedir.

Çalışmanın bundan sonraki aşamasında finansal okuryazarlığa etki edecek değişkenlere ilişkin t-testi ve varyans analizi sonuçlarına yer verilmiştir.

Tablo 10. Finansal Okuryazarlığa Etki Eden

Değişkenleri Belirlemeye Yönelik t-testi ve Varyans Analizi Sonuçları

\begin{tabular}{|c|c|c|c|c|}
\hline & Değişkenler & $\begin{array}{c}\text { Finansal } \\
\text { Okuryazarlık }\end{array}$ & & \\
\hline & & Ortalama & Test & Sig. \\
\hline \multirow{2}{*}{ Cinsiyet } & Kadın & 3,5815 & \multirow{2}{*}{$-5,268$} & \multirow{2}{*}{, $000^{*}$} \\
\hline & Erkek & 3,8308 & & \\
\hline \multirow{2}{*}{ Kadro } & Akademisyen & 3,7493 & \multirow{3}{*}{841} & \multirow{3}{*}{,360 } \\
\hline & Memur & 3,7032 & & \\
\hline \multirow{5}{*}{ Yaş } & $18-25$ yaş & 3,7694 & & \\
\hline & $26-33$ yaş & 3,6737 & \multirow{4}{*}{1,687} & \multirow{4}{*}{ 153 } \\
\hline & $34-41$ yaş & 3,6719 & & \\
\hline & $42-49$ yaş & 3,8177 & & \\
\hline & $50+$ & 3,7916 & & \\
\hline \multirow{3}{*}{ Medeni Durum } & Bekâr & 3,6253 & \multirow{2}{*}{2,643} & \multirow{2}{*}{, $009^{*}$} \\
\hline & Evli & 3,7648 & & \\
\hline & Lise & 3,7154 & \multirow{3}{*}{,899 } & \multirow{3}{*}{,408 } \\
\hline \multirow[t]{2}{*}{ Eğitim Durumu } & Lisans & 3,7919 & & \\
\hline & Lisansüstü & 3,7032 & & \\
\hline \multirow{4}{*}{ Gelir Grupları } & $2501-3500 \mathrm{TL}$ & 3,7493 & \multirow{4}{*}{, 160 } & \multirow{4}{*}{,326 } \\
\hline & $3501-4500 \mathrm{TL}$ & 3,6590 & & \\
\hline & $4501-5500 \mathrm{TL}$ & 3,6630 & & \\
\hline & $5501 \mathrm{TL}+$ & 3,7673 & & \\
\hline \multirow{4}{*}{ Finans Takibi } & Takip etmem & 3,6849 & \multirow{4}{*}{2,700} & \multirow{4}{*}{, $046^{* *}$} \\
\hline & $\mathrm{TV}$ & 3,6816 & & \\
\hline & Gazete & 3,6531 & & \\
\hline & İnternet/mobil & 3,8227 & & \\
\hline \multirow{2}{*}{ Finansal Varlıklar } & Yok & 3,6047 & \multirow{2}{*}{$-2,526$} & \multirow{2}{*}{, $012^{* *}$} \\
\hline & Var & 3,7542 & & \\
\hline
\end{tabular}

*** sırasılla değişkenlerin \%1 ve \%5 önem düzeyinde istatistiksel anlamlılıklarını göstermektedir.

Bulgulara göre cinsiyet, medeni durum, finans takibi ve finansal varlıkların finansal okuryazarlık üzerindeki etkisinin önemli olduğu tespit edilmiştir. Diğer bir ifade ile erkek çalışanların kadın çalışanlara, evli çalışanların bekâr çalışanlara ve finansal varlık sahiplerinin varlık sahibi olmayanlara göre finansal okuryazarlık düzeylerinin daha yüksek olduğu ve bu farkın istatistiksel olarak anlamlı olduğu elde edilmiştir. Çalışanların finansal okuryazarlık düzeyi finans takibine göre farklılık göstermektedir. Farklılı̆̆ın hangi gruptan meydana geldiğini tespit etmek için Post Hoc testleri uygulanmıştır. Bu testlerden önce varyansların homojenliğini adına Levene sınaması kontrol edilmiştir. Levene test değeri 0.245 olup, 
anlamlılık değeri 0.865 'tir. Dolayısıyla varyansların homojen olduğu tespit edilmiş olup Tukey sınamasından yararlanılmıştır.

Tablo 11. Finans Takibinin Finansal Okuryazarlık Düzeyi ile Çoklu Karşılaştırma Tablosu

\begin{tabular}{|c|c|c|c|}
\hline & & Ortak Farklar & Anlamlılık Düzeyi \\
\hline \multirow[t]{3}{*}{ Takip Etmem } & TV & ,0033 & 964 \\
\hline & Gazete & ,0318 & 652 \\
\hline & İnternet/Mobil &,$- 1377^{*}$ & ,025 \\
\hline \multirow[t]{3}{*}{ TV } & Takip Etmem &,- 0033 & ,964 \\
\hline & Gazete & ,0284 & ,728 \\
\hline & İnternet/Mobil &,$- \mathbf{1 4 1 1}^{*}$ & ,057 \\
\hline \multirow[t]{3}{*}{ Gazete } & Takip Etmem &,- 0318 & 652 \\
\hline & $\mathrm{TV}$ &,- 0284 & 728 \\
\hline & İnternet/Mobil &,$- 1695^{*}$ & ,017 \\
\hline \multirow[t]{3}{*}{ İnternet/Mobil } & Takip Etmem & $1377^{*}$ & ,025 \\
\hline & TV & ,1411* & ,057 \\
\hline & Gazete & ,1695* & ,017 \\
\hline
\end{tabular}

*, Ortalama farkın 0,5 önem seviyesinde anlamlı olduğunu gösterir.

Tablo 11'deki sonuçlara göre, üniversite çalışanlarında internet/mobil kullananların finansal okuryazarlık düzeylerinin diğerlerine göre istatistiksel olarak anlamlı bir farklılık gösterdiği elde edilmiştir.

\section{Sonuç}

$\mathrm{Bu}$ çalışmada finansal tutum, kişisel servet, finansal stres, finansal davranış ve finansal bilgi olmak üzere üniversite personelinin finansal okuryazarlığını düzeyini belirleyecek bir ölçekten yararlanılmıştır. Her bir alt ölçekten elde edilecek yüksek puanlar kişilerin finansal okuryazarlıklarının yüksek olacağını belirtmektedir.

Gerçekleştirilen açıklayıcı faktör analizi sonuçları, alt ölçeklerin toplam varyansın \%38 ile \%65 arasını açıklayabildiğini göstermiştir. Ayrıca her bir alt ölçeğe ilişkin elde edilen faktör yükleri istatistiksel olarak anlamlı bulunmuştur. Gerçekleştirilen ankete ilişkin, 4 farklı alt ölçeklerin Cronbach Alfa değerleri güvenilir sonuçların elde edildiğini göstermiştir.

Her bir alt ölçeğe ilişkin uygulanan uyum iyiliği kriterleri de sonuçların kabul edilebilir ve iyi bir uyum seviyesinde olduğunu işaret etmiştir.

Beş farklı ölçekten hareketle oluşturulan finansal okuryazarlık düzeyi üzerinde üniversite çalışanlarının cinsiyeti, medeni durumu, sahip olup olmadıkları finansal varlıkları ve finansal piyasayı takip etme şekilleri istatistiksel olarak anlamlı olmuştur. İkiden fazla türde finansal piyasayı takip etme kriterini içeren çalışma da internet ve mobil uygulamalar diğer türlere göre finansal okuryazarlık düzeyinde anlamlı sonuçlar göstermiştir.

Finansal okuryazarlık konusu toplumun geneli için oldukça önemlidir. Ancak özellikle iş hayatında yer alan üniversite personeli için ayrı bir önem teşkil etmektedir. Finansal konularda daha net ve sağlam tercihlerde bulunabilen, finans alanında bilinçli ve geleceğe dair öngörü yetisi yüksek kişilerin olması bu alanda önemli kararların alınmasını sağlayacaktır. Ayrıca finans derslerinin sadece üniversitelerde yer almasıyla kalmayıp ortaöğretim 
müfredatına yerleştirilerek daha bilinçli finansal okuryazar bireylerin yetişmesi sağlanmalıdır. Bilimsel olarak, finansal okuryazarlık adına gerek tutum ve davranış gerekse de bilgiye yönelik ölçek araçlarının geliştirilmesi ya da yeni ölçme türlerinin incelenmesi hususunda metodolojik çalışmaların arttırılması gerekmektedir. Ayrıca finansal tutum ve davranışların yanı sıra sosyal, kültürel ve beşerî faktörlerin de etkisi araştırılmalıdır.

\section{Kaynakça}

Ansong, A. \& Gyensare, M. A. (2012). Determinants of university working-students' financial literacy at the university of Cape Coast, Ghana, International Journal of Business and Management, 7 (9), 126-133.

Atkinson, A. \& Messy, F. (2012). Measuring financial literacy: results of the OECD / International Network on Financial Education (INFE) pilot study, OECD Working Papers on Finance, Insurance and Private Pensions, No. 15.

Bayram, N. (2016). Yapısal eşitlik modellemesine giriş: amos uygulamaları, Ezgi Kitapevi, Bursa.

Bayram, N. (2017). Sosyal bilimlerde spss ile veri analizi, Ezgi Kitabevi, Bursa.

Chen, H. \& Volpe, R.P. (1998). An analysis of personal financial literacy among college students, Financial Services Revenue, 7 (2), 107-128.

Chinen, K. \& Endo, H. (2012). Effect of attitude and bacground on personal finance ability: a student survey in the united state, International Journal of Management, (29).1: 33-45.

Criddle, E. (2006). Financial literacy: goals and values, not just numbers, Alliance , (34),4. 86102.

Danes, S.M. \& Haberman, H.R. (2007). Teen financial knowledge, self efficacy, and behavior: a gendered view, Financial Counseling Planning, 18 (2), 48-60.

Ergün, K. (2018). Üniversite öğrencilerinin finansal okuryazarlı̆̆ı: balıkesir üniversitesi örneği, Yayınlanmamış Doktora Tezi, Balıkesir Üniversitesi Sosyal Bilimler Enstitüsü.

Hung, A., Parker, A. \& Yoong, J. (2009). Defining and measuring financial literacy, RAND Working Paper 708.

Huston, S.J. (2010). Measuring financial literacy, Journal of Consumer Affairs, 44 (2), 296-316.

International Wellbeing Group (2013). Personal wellbeing index (Adult),Manual (5th edn.).

Johnson, A.C. (2001). Evaluating a financial assessment tool: the financial checkup (Dissertation), Utah University, United States.

Joo, S. (2008). Personal financial wellness, In J. J. Xiao (Ed.), Handbook of consumer research (pp. 21-33), New York: Springer.

Jorgensen, B. L. \& Savla, J. (2010). Financial literacy of young adults: the importance of parental socialization, Family Relations, 59, 465-478.

Kalayc1, Ş. (2006). SPSS uygulamalı çok değişkenli istatistik teknikleri, Asil Yayıncılık, Ankara.

Knoll, M. A. Z. \& Houts, C.R. (2012). The financial knowledge scale: an application of item response theory to the assessment of financial literacy, Journal of Consumer Affairs, 46 (3), $381-410$. 
Louw, J., Fouché, J. \& Oberholzer, M. (2013). Financial literacy needs of south African thirdyear university students, International Business \& Economics Research Journal, 12(4):439-450.

Lusardi, A. \& Tufano, P. (2008). Debt literacy, financial experience, and overindebtedness, Harvard Business School, Working Paper.

Lusardi, A. \& Mitchell, O.S. (2013). The economic importance of financial literacy: theory and evidence, Nber Working Paper, 18952.

Mandell, L.(2007). Financial literacy of high schools students. in: handbook of consumer finance research, Springer, New York.

Potrich, A. C. G., Vieira K. M., Coronel, D. A. ve Filho, R. B.(2015). Financial literacy in Southern Brazil: modeling and invariance between genders, Journal of Behavioral And Experimental Finance, 6, 1-12.

Prawitz, A.D., Garman,E.T, Sorhaindo,B., O’Neill, B., Kım, J. \& Drentea, P. (2006). In charge financial distress/financial well-being scale: development, administration, and score interpretation, Financial Counseling and Planning, 17 (1), 34-50.

Robb, C.A., Babiarz, P., \& Woodyard, A. (2012). The demand for financial professionals' advice: the role of financial knowledge, satisfaction, and confidence, Financial Services Revenue, 21 (4), 291-305.

Saunders, M., Lewis, P. \& Thornhill, A. (2000). Research methods for business students, Second Edition, Prentice-Hall Financial Times, England.

Schumacher, R. E. \& Lomax, R. G. (2010). A Beginner's guide to structural equation modelling, (3rd ed.) London, New York: Routledge.

Shockey, S. (2002). Low-wealth adult's financial literacy: money management behavior and associates factors, including critical thinking, Unpublished Doctoral Dissertation, The Ohio State University (AAT 3039524).

Sohn, S.H., Joo, S.H., Grable, J.E., Lee, S., \& Kım, M. (2012). Adolescents' financial literacy: the role of financial socialization agents, financial experiences, and money attitudes in shaping financial literacy among South Korean youth, Journal of Adolescence, 35, 969-980.

Taft, M. K., Hosein, Z. Z. \& Mehrizi, S. M.T. (2013). The Relation between financial literacy, financial wellbeing and financial concerns, International Journal of Business and Management, $8(11), 63-75$.

Taylor, S. \& Wagland, S. (2013). The solution to the financial literacy problem: what is the answer?, Australasian Accounting Business \& Finance Journal, 7(3), 69-89.

Temizel, F. \& Bayram, F. (2011). Finansal okuryazarlık: anadolu üniversitesi iktisadi ve idari bilimler fakültesi öğrencilerine yönelik bir araştırma, C. Ü. İktisadi ve İdari Bilimler Dergisi, 12(1), s. 73-86.

Winkielman, P., Halberstadt, J., Fazendeiro, T. \& Catty, S. (2006). Prototypes are attractive because they are easy on the mind, Psycholical Science, 17 (9), 799-806.

Xiao, J.J., Tang, C., Serido, J. \& Shim, S. (2011). Antecedents and consequences of risky credit behavior among college students: application and extension of the theory of planned behavior, Journal of Public Policy Marketing, 30 (2), 239-258. 
Üniversite Çalışanlarının Finansal Okuryazarlık Düzeylerinin Belirlenmesine Yönelik Bir Araştırma

Yılmaz, V. \& Varol, S. (2015). 4. Hazır yazılımlar ile yapısal eşitlik modellemesi amos, eqs, lısrel, Dumlupınar Üniversitesi Sosyal Bilimler Dergisi, 44,28-44. 